\title{
Non-thermal Treatments for Food Preservation
}

\author{
Saúl David Buelvas-Caro, María Camila Assia-Ortiz and Liliana Polo-Corrales* \\ Department of Agroindustrial Engineering, Innovation and Development of Food \\ Processes (DESINPA) - Universidad de Sucre, Carrera. 28 \#5-267, \\ Puerta Roja, Sincelejo, Colombia; sauldavidbuelvas@gmail.com, \\ assiamariac@gmail.com, liliana.polo@unisucre.edu.co
}

\begin{abstract}
Objectives: The purpose of this work was to review the recent advances in the non-thermal treatments for food preservation such as ultrasound, microwave, ultraviolet irradiation, electric field, electromagnetic field, and high hydrostatic pressure. Methods/Statistical Analysis: In order to elaborate this review, it was performed the following procedure: First, by the use of databases available, the principal findings published related to the non-thermal treatments used to preserve specific food product were chosen. Second, the principal characteristics such as conditions of operation, effects on mechanical and physicochemical properties, and relevant results were highlighted from each study. Third, a short description of each study was realized. Findings: In this review, the non-thermal treatments can generate in food minimal alterations of the physicochemical and mechanical properties, stimulate the production of edible microorganism, generate localized heating conserving its nutritional quality, promote the enzymatic inactivation, and have antimicrobial effects. Application/Improvements: Non-thermal treatments used for sterilization process in food can implement the use of others technologies such as example the nanostructured materials used in the fabrication of food packaging, the use of different types of food packaging i.e., active, intelligent, biodegradable, the application of treatments such as the use of nzyme or biopreservation, and the incorporation of bio-compounds.
\end{abstract}

Keywords: Electric Pulses, Electromagnetic Pulses, Food Preservation, Hydrostatic Pressure, Microbial Inactivation, Microwave, Ultrasound

\section{Introduction}

Reduction of the microbial load and the water activity is an objective of food preservation 1 . The microbial load is referred to as microorganisms and enzymes that cause food spoilage. Water activity determinates the amount of water available that can participate in the chemical reactions in food such for example the microbiological growth ${ }^{2}$. At the same time, food deterioration process is catalyzed by environmental factors (i.e., temperature, humidity, oxygen, and light) that trigger this effect and have repercussions on the product acceptability by consumers ${ }^{3}$.

The preservation methods looking for securing and guaranteeing the food integrity by the inactivation of pathogen and microorganism without modifying its organoleptic and nutritional characteristics. Nowadays, the thermal treatments in the food industry are used to inactive the microbial and enzymatic process, although, specific microorganism, such as spores from bacteria, are not susceptible to the effects antimicrobial of heat treatments $s^{4,5}$.

Therefore, in the last years, non-thermal technologies are being used to inactivate these microorganisms, obtaining food product sterilized and with high nutritional quality. New non-thermal technologies such as ultrasound, microwave, ultraviolet irradiation, electric and electromagnetic pulses, and high hydrostatic pressure are being applied to the inactivation of the microbial load at temperatures close to the environment ${ }^{6}$.

In this review are highlighted recent studies performed in the different types of non-thermal technologies such

${ }^{*}$ Author for correspondence 
as ultrasound, microwave, ultraviolet irradiation, electric and electromagnetic pulses, and high hydrostatic pressure, which are focused onobtaining of pathogen-free food (Figure 1).

\section{Non-Thermal Treatments}

\subsection{Ultrasound}

UltraSound (US) are an oscillating sound pressure wave that generates changes to the local level, for example, the medium's density and pressure. At the same time, the ultrasound exerts both thermal and non-thermal effects on liquids and in soft tissues ${ }^{7}$. This type of energy produces pressure waves with frequency upper to $20 \mathrm{KHz}$ and can be divided into two categories: low intensity (i.e., frequency $>100 \mathrm{kHz}$ with intensities $<1 \mathrm{~W} / \mathrm{cm} 2$ ) and high intensity (i.e., $20 \mathrm{kHz}<$ frequency $>500 \mathrm{kHz}$ with intensities $>1 \mathrm{~W} / \mathrm{cm} 2)^{6,8}$. Nowadays, this technology is being used in the processes for food products elaboration and their sterilization. In the food industry, this method allows the inactivation of microorganism due to the capacity of the ultrasound to generates damage to cell level by breakage of the cell walls, disruption and thinning of cell membranes, and DNA damage via free radical production? ${ }^{9}$. This technology is useful for the conservation of the product and has potential in the food industry to develop safe, economical processes that positively affect the properties of food.

Recently, researchers have reported the use of ultrasound to food conservation. Aspects such as the microbiological quality (i.e., i.e., mesophiles, total coliforms, and fecal) and functional properties (i.e., $\mathrm{pH}$ and stability of the emulsions) of buffalo meat (Bubalus bubalis) have been evaluated under the combined ultrasound and magnetic fields. The results indicated that the exposition to both physical stimuli increased the stability of the emulsions with a decrease in $\mathrm{pH}$ and stimulated the antimicrobial activity ${ }^{10}$. Similarly, evaluated the effects produced by the exposition to the ultrasound and the magnetic fields on $\mathrm{pH}$, texture profile and color in tuna loin meat (Thunnus albacares). According to the results of this study, the combination of these effects generated changes in mechanical properties (i.e., a decrease of hardness and elasticity) and the color of the meat ${ }^{\underline{6}}$.

In the same way, in products such as the milk and vegetables also have been evaluated the effects caused by the exposition to several ultrasound intensities.

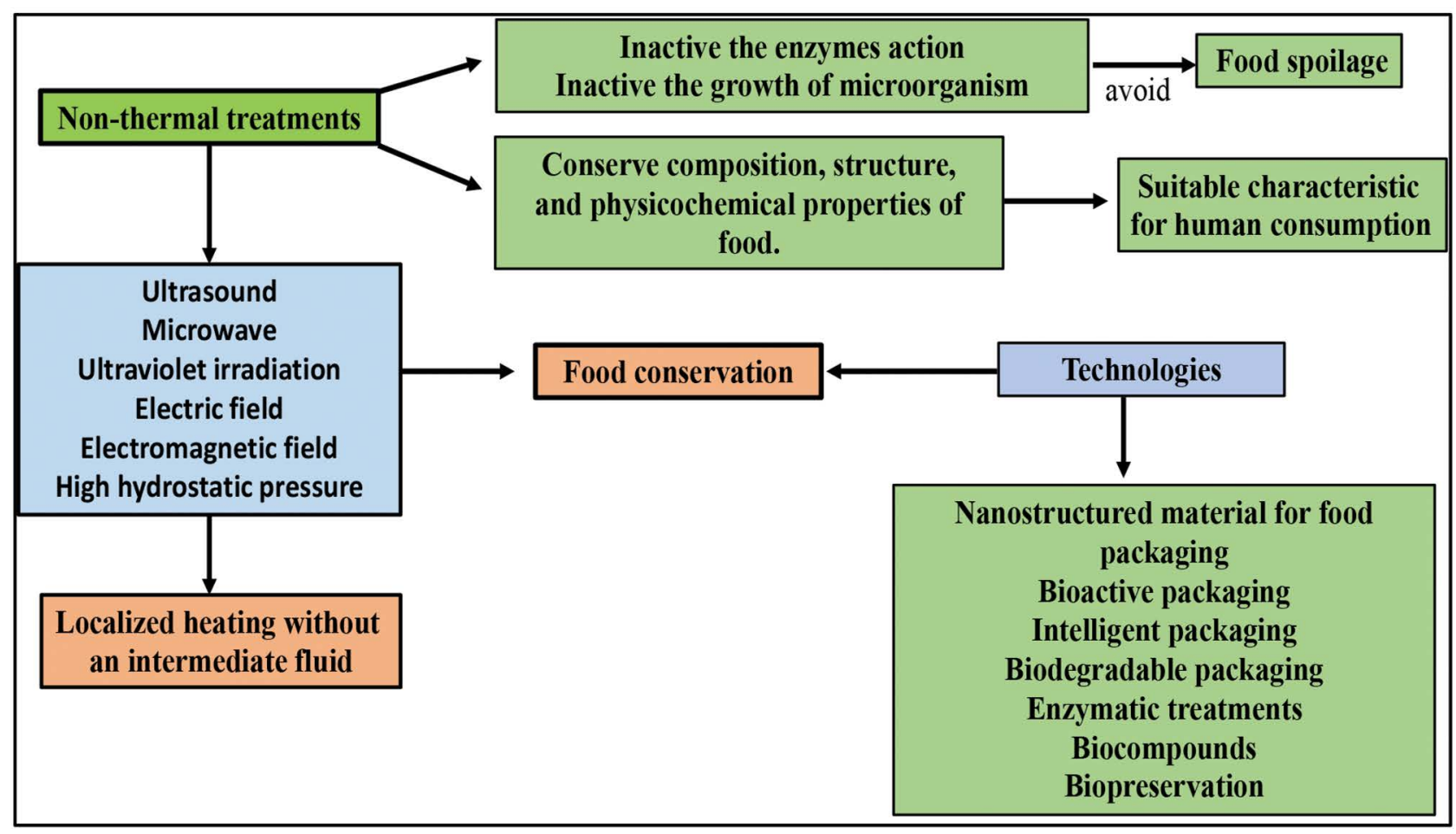

Figure 1. Non-thermal treatment used in the food industry. 
Gelvez-Ordoñes and coworkers $(2015)^{\underline{11}}$, proved packed milk under vacuum to thermosonication $(40 \mathrm{KHz})$ at temperatures of $40,50,60$ and $70^{\circ} \mathrm{C}$, for 30 minutes. This treatment positively affected the $\mathrm{pH}$, acidity and viscosity parameters of milk during storage; except for the density that did not show significant changes. The treatments that conserved the parameters within the allowed ranges of the milk during the 15 days were those that used sound waves at $40 \mathrm{kHz}$ at temperatures of $60^{\circ} \mathrm{C}$ during $30 \mathrm{~min}$. Likewise, the effects of ultrasound in vegetables are used principally to their disinfection without altering the physicochemical properties. In their study examined the microbicidal activity of Slightly Acid Electrolyzed Water (SAEW) in col Chinese, lettuce, sesame leaves, and spinach, four fresh vegetables common in Korea ${ }^{12}$. These researchers indicated that a simultaneous treatment with SAEW with ultrasound at $40 \mathrm{kHz}$ followed by washing with water at room temperature produced improved microbial reductions of Escherichia coli O157: H7, Listeria monocytogenes, yeasts, and molds in these vegetables species.

Similarly, experimented with ultraviolet light (UV $254 \mathrm{~nm}$ ) and ultrasound (frequency of $37 \mathrm{kHz}$ and a power of up to $30 \mathrm{~W} / \mathrm{L}$ ) to inactive bacteria (i.e., E coli, Listeria innocua, Salmonella enteritidis and Staphylococcus aureus) in lettuce and strawberries ${ }^{-}$. The results of this study demonstrated the antimicrobial effect caused by this biophysical stimulation without altering the color of the vegetables. Besides, the combination of ultrasounds and surfactants to reduce the spores of Bacillus cereus in lettuce and carrots have demonstrated to be an alternative method to conventional disinfectants containing chlorine ${ }^{\underline{13}}$. In this study, the combination of ultrasound and $0.1 \%$ Tween 20 produced reductions of the levels of spores of B.cereus in lettuce and carrots, respectively, without causing a deterioration in their quality.

Likewise, it has found that ultrasound stimulates the production of edible fungi. $\operatorname{In}^{14}$ analyzed the effects of ultrasound treatment on the physicochemical characteristics of species of edible fungi Pleurotus ostreatus. These researchers exposed packed samples in low-density polyethylene bags with a vacuum of $60 \%$ at $40 \mathrm{KHz}$ with different temperatures 20,40 and $60^{\circ} \mathrm{C}$ for several times periods. The changes in the characteristics of color, $\mathrm{pH}$ and enzymatic activity storage under refrigeration conditions determined that the best condition for fungi growth under ultrasound be at $40{ }^{\circ} \mathrm{C}$. In Table 1 described some studies related to ultrasound treatment for food preservation.

\subsection{Microwave}

Microwaves are electromagnetic waves generated in the frequency range between $300 \mathrm{MHz}$ and $3000 \mathrm{MHz}$. This type of waves is found between the infrared and radio waves. The effects caused by the microwave radiation are subjected to the electrical properties of the material ${ }^{15}$.

Food can store and dissipate electric energy when subjected to an electromagnetic field due to their poor insulator properties and dielectric properties ${ }^{16}$. Also, the use of Microwave Assisted Thermal Sterilization (MATS) is being used as an alternative for sterilization of food. In this technique, the food products are exposed to 915 $\mathrm{MHz}$ frequency microwave energy with the purpose of reaching internal heating homogeneous. Dr. Juming Tang's Microwave Group at Washington State University developed this technology ${ }^{17}$. The food industry uses this type of stimulation for food preparation and conservation. The objective of this technique is obtaining localized heating without the usage of an intermediate fluid 18,19 .

The application of this technique in the food conservation is focused in Microwave Assisted Pasteurization and Sterilization without altering the properties physicochemical and organoleptic characteristics of food. Likewise, this technique is used for the process such as thawing and tempering, precooking and cooking, baking, drying, and blanching ${ }^{20}$.

The effect of microwave sterilization on fruit, fruitcake, and vegetable ${ }^{21-} \underline{24}$, mashed ${ }^{25}$, meat products (i.e., stewed pork liver and recombinant meat) ${ }^{26}$, cereals (i.e., rice, rice noodles) ${ }^{27}$, etc., are some examples of the application of microwave stimulation in food preservation. The stimulation by microwaves has allowed not only the inhibition of microorganism activity and the degree of browning, but also, the conservation of the nutritional content, color, and texture ${ }^{19}$.

Recenty, some studies have determined the electromagnetic energy from the microwave works favorably in the process of destruction of fungus. It has found that the microwaves achieve to inactivate the microbial load and preserve the attributes of mango juice (i.e., $\mathrm{pH}$ and soluble solids concentration). In this study, the juice was subjected to the action of microwave (2450 MHz and power $1.5 \mathrm{~kW}$ ) resulting in the decrease of microbial population of filamentous fungi Aspergillus $\mathrm{sp}^{28,29}$. Similarly, this technique has been used in the pas- 
Table 1.Ultrasound treatment for food preservation and processing

\begin{tabular}{|c|c|c|}
\hline Food Products & Operation Conditions & Principal Results \\
\hline Emulsion of buffalo meat (Bubalus bubalis). & $\begin{array}{l}37 \mathrm{kHz} \text { and } 0.1147 \mathrm{~T} \text {. Temperature of } \\
16^{\circ} \mathrm{C} \text {. }\end{array}$ & $\begin{array}{l}\text { Reduction of mesophiles and total } \\
\text { coliforms. }\end{array}$ \\
\hline Tuna meat (Thunnus albacares). & $\begin{array}{l}37 \mathrm{kHz}, 25 \mathrm{~W} / \mathrm{cm}^{2} \text {, and } 1 \text { Tesla. } \\
\text { Temperature of } 18^{\circ} \mathrm{C} .\end{array}$ & Decrease of hardness and elasticity \\
\hline Milk & $\begin{array}{l}\text { Thermosonication }(40 \mathrm{KwHz}) \text { to } \\
\text { temperatures of } 40,50,60 \text { and } 70{ }^{\circ} \mathrm{C} \\
\text { for } 30 \text { minutes. }\end{array}$ & $\begin{array}{l}\text { The treatment positively affects color, } \\
\text { pH, acidity and viscosity of milk. }\end{array}$ \\
\hline $\begin{array}{l}\text { Chinese cabbage, lettuce, sesame } \\
\text { leaf and spinach }\end{array}$ & $\begin{array}{l}\text { Simultaneous slightly acid electrolyzed } \\
\text { water }(\mathrm{SAEW}) \text { treatment }+40 \mathrm{kHz}\end{array}$ & $\begin{array}{l}\text { Reductions of E. coli O157:H7 and L. } \\
\text { monocytogenes }\end{array}$ \\
\hline Lettuce and strawberry & $\begin{array}{l}\text { Frequency of } 37 \mathrm{kHz} \text { and a power up } \\
\text { to } 30 \mathrm{~W} / \mathrm{L} \text { ) during } 10,20,30,45 \text { and } \\
60 \mathrm{~min} .\end{array}$ & Reduction of E. coli and S. Enteritidis. \\
\hline
\end{tabular}

teurization of orange juice. In this study, the juice was exposed to at various temperatures (i.e., 60, 70, 75 and $85^{\circ} \mathrm{C}$ ) in an oven microwave with $3 \mathrm{~kW}$ and frequency of $2.45 \mathrm{GHz}$ where the activity of Pectin Methyl Esterase (PME), color, compounds of carotenoids and the content of vitamin $\mathrm{C}$ were monitored. The results showed the stabilization of fresh juice by the inactivation of the enzyme activity 28 .

Likewise, De la Vega-Miranda and coworkers analyzed the treatment of water-assisted microwave against the pathogenic bacterium Salmonella typhimurium in Jalapeno and cilantro fresh. These researchers found a feasible option of thermal treatment using a domestic microwave. Jalapeño and cilantro were exposed to 950 Watt for 25 seconds and 10 seconds, respectively. In both vegetables, it was seen a reduction of the population of bacteria with no changes in their firmness. Besides, changes in the color of the vegetables were seen, but no sensory acceptance was affected ${ }^{30}$. On the other hand, similar results were obtained in the beef meat using different times of radiation $(10,20,30,40$ and $50 \mathrm{~s})$. The results of this study showed a total elimination of E. coli O157: H7 after the end of the exposure time of $30 \mathrm{~s}$, when the surface temperature increased to $73^{\circ} \mathrm{C}^{31}$. Finally, researchers also have obtained extracts from thinned nectarines, which can block the action of the polyphenoloxidase enzyme. Studies in minimally processed peaches have demonstrated this effect $\frac{32}{}$. In Table 2 described some studies related to microwave treatment used in food preservation.

\subsection{Ultraviolet Irradiation}

Ultraviolet light has three regions: UV-A, UV-B, and UV-C, which corresponds to $315-400 \mathrm{~nm}, 280-315 \mathrm{~nm}$, and 200-280 $\mathrm{nm}$ respectively ${ }^{33}$. USDA (United States Department of Agriculture, USA) has approved the use of the irradiation light (UV-C) in food products for the disinfection process ${ }^{34}, \underline{35}$. This type of irradiation causes damage a cell level because of the formation of thymine dimers that inactive the DNA transcription and replication ${ }^{35}, \underline{36}$. Researchers have indicated that this technique is very secured due to the reduced potency of the gamma rays that can make the food radioactive and the no direct contact with the food during the exposition ${ }^{37}$. Nevertheless, the lack of studies that predict the surface disinfection rate and the high cost in operation of this technique have caused that this technology is not widely applied $^{38}$.

Recent studies have reported that UV-C can disinfect a wide variety of fruits with slight changes in its physicochemical properties ${ }^{39}$. Also, similar effects have been observed in eggs ${ }^{40}$. Researchers have found that UV-C irradiation on Dragon fruit (Hylocereusundatus (Haw) Britt. and Rose) decreased the microbial growth of bacteria, coliforms, yeast, and mold ${ }^{35}$. Also, a study has evaluated the UV-C light effects on the structure, color and the sensory properties of fresh-cut apples ${ }^{41}$. The results of this study showed that the application of this technique generated an antimicrobial effect in the fruits. Although, the fruits exposed to values above 1.2 $\mathrm{kJ} / \mathrm{m} 2$ presented dehydration and oxidation.Likewise, 
Table 2. Micro wave treatment for food preservation

\begin{tabular}{|c|c|c|}
\hline Food Product & Operation Conditions & Principal Results \\
\hline Mango juice & $2450 \mathrm{MHz}$ microwave and $1.5 \mathrm{~kW}$ power. & $\begin{array}{l}\text { Reduction of filamentous } \\
\text { fungi Aspergillus sp. }\end{array}$ \\
\hline Peach fruit nectar (Prunus persica (L.) & High levels of microwave power $(500,1000$ and & Inhibition of enzymatic \\
\hline Batschvar. Laura nectarine) & $1500 \mathrm{~W})$ & $\begin{array}{l}\text { browning in minimally } \\
\text { processed peaches during } 8 \\
\text { days of storage. }\end{array}$ \\
\hline Orange Juice & $\begin{array}{l}3 \mathrm{~kW} \text { and standard frequency of } 2.45 \mathrm{GHz} \text { at } \\
\text { different temperatures }\left(60,70,75 \text {, and } 85^{\circ} \mathrm{C}\right) \text {. }\end{array}$ & $\begin{array}{l}\text { Inactivation of pectin methyl } \\
\text { esterase (PME), decreased } \\
\text { content of carotenoids and } \\
\text { ascorbic acid. }\end{array}$ \\
\hline Jalapeño peppers and coriander foliage & $950 \mathrm{~W}$ to reach up $63^{\circ} \mathrm{C}$ for 10 and $25 \mathrm{~s}$. & $\begin{array}{l}\text { Reduction of Salmonella } \\
\text { population. }\end{array}$ \\
\hline Beefcattleslices & $\begin{array}{l}2450 \mathrm{MHz} \text { and } 850 \text { watts and radiation for } \\
10,20,30,40 \text { and } 50 \mathrm{~s} .\end{array}$ & $\begin{array}{l}\text { Total reduction of E. coli } \\
\text { O157: H7. }\end{array}$ \\
\hline
\end{tabular}

the impact of this technique on the safety and quality of fresh melon during cutting and before packaging also has been evaluated ${ }^{39}$. According to the results, it was produced various effects such as the reduction in the growth of Enterobacteriaceae, the decrease of the filtration, and no significant changes on the color and the firmness of the product during storage at $6{ }^{\circ} \mathrm{C}$ for 14 days.

Studies realized fruits such as mango, pineapple and mamey minimally processed demonstrated that radiation dose UV-C (i.e., 0,7 and $14 \mathrm{~kJ} / \mathrm{m}^{2}$ ) does not alter their physico-chemical, microbiological and antioxidants characteristics. The dose of UV-C irradiation of $14 \mathrm{~kJ} / \mathrm{m}^{2}$ allowed to obtain higher antioxidant properties and lower microbial count of aerobic mesophilic bacteria, fungi and yeasts ${ }^{42}$. Another study also has highlighted the antimicrobial effect of UV-C irradiation in apples, pears, strawberries, red raspberries and melons ${ }^{43}$. This study the rates inactivation of Escherichia coli O157: H7 and Listeria monocytogenes were higher for fruits less hydrophobic with most smooth surfaces (apples and pears) compared with fruits (i.e., melon, strawberry, and raspberry) over rough surfaces. By last, a finding has reported that the combination of immersion solutions containing malic acid and treatment with UV-C light reduces the growth of Salmonella Poona and 1. monocytogenes in fresh-cut papaya ${ }^{44}$. In Table 3 are described some studies related to ultraviolet irradiation treatment for food preservation.

\subsection{Pulsed Electric Fields (PEFs)}

Pulsed Electric Fields (PEF) decontaminate the food because to reduce their enzyme activity ${ }^{45}$. This technique consists in the application of high voltage electric fields with short duration pulses (i.e., $\mu$ s to $\mathrm{ms}$ ). This effect causes the electroporation, which permeabilizes of cell membranes $s^{46,47}$. This technique reduces the heat amount used for complete the enzyme inactivation during the blanching process ${ }^{48}$. Also, it can modulate the activity of the enzyme Poly-Phenol Oxidases (PPOS) ${ }^{49}$. Moreover, it has demonstrated that a Concentrated High Intensity Electric Field (CHIEF) produces the same antimicrobial effects generated during a pasteurization process traditional ${ }^{50}$.

Recent studies in this field have demonstrated that pulsed electric field reduces the mechanical force allowing decreasing the intensity of the cutting force in carrots and achieving at the same time an enhancement in the cutting quality. Therefore, the application of this treatment before blanching could secure the enzyme inactivation in vegetables ${ }^{48}$. The effect of pulsed electric fields on the final quality of potatoes for frying fat also has been studied $^{47,51,52}$. The electroporation causes specific structural changes in the vegetal tissues, which resulted in lower absorption of oil in the potato.

The application of this technology in the conservation of juices also has been investigated. It has reported studies that indicate PEF combined with bioactive agents $s^{53}$ and antimicrobial bottles ${ }^{54}$ exerts a bactericidal effect on the food. The use of PEF in orange juice with nisin and 
Table 3. Ultravioletlight treatment for food preservation

\begin{tabular}{|c|c|c|}
\hline Food Product & Operation Conditions & Principal Results \\
\hline Fresh-cutapple & $\begin{array}{l}\text { UV-C light treatments at } 1.2,6.0,12.0 \text { and } 24.0 \\
\mathrm{~kJ} / \mathrm{m}^{2} \text {. }\end{array}$ & Germicidal effect \\
\hline Fresh-cutmelon & $\begin{array}{l}\text { UV-C light fluence were } 0,1200,6000 \text { and } 12,000 \\
\mathrm{~J} / \mathrm{m}^{2} \text {. Irradiance of } 20 \mathrm{~W} / \mathrm{m}^{2} \text { increasing time up } \\
\text { to } 10 \mathrm{~min} \text {. }\end{array}$ & $\begin{array}{l}\text { Reduction of Enterobacteriacea } \\
\text { growth. }\end{array}$ \\
\hline Mango, pineapple and mamey & $\begin{array}{l}\mathrm{UV}-\mathrm{C}\left(0,7 \text { and } 14 \mathrm{~kJ} / \mathrm{m}^{2}\right) \text { stored for } 15 \text { days at } 5^{\circ} \\
\mathrm{C} \text { and } \mathrm{HR} \text { of } 85-90 \%\end{array}$ & $\begin{array}{l}\text { Reduction of } 0.89,1.5 \text { y } 2.26 \log \mathrm{CFU} / \mathrm{g} \\
\text { in mango, pineapple and mamey, } \\
\text { respectively. }\end{array}$ \\
\hline $\begin{array}{l}\text { "Maradol" red papaya (Carica } \\
\text { papaya } \mathrm{L})\end{array}$ & UV-C light $\left(0,0.96,2.88,5.76\right.$ and $\left.8.64 \mathrm{~kJ} / \mathrm{m}^{2}\right)$ & $\begin{array}{l}\text { Reductions of } 5.28 \text { and } 3.15 \log _{10} \\
\text { CFU/g for SalmonellaPoona and } L . \\
\text { monocytogenes, respectively. }\end{array}$ \\
\hline $\begin{array}{l}\text { Apples, pears, strawberries, red } \\
\text { raspberries and cantaloupes }\end{array}$ & $\begin{array}{l}\mathrm{UV}-\mathrm{C} \text { light does up to } 11.9 \mathrm{~kJ} / \mathrm{m}^{2} \text { at } 23^{\circ} \mathrm{C} \text { with } \\
\text { exposure times between } 0-14 \mathrm{~min} \text {. }\end{array}$ & $\begin{array}{l}\text { Reduction of E. coli O } 157 \text { and } L . \\
\text { monocytogenes in apples, pears, } \\
\text { strawberries and raspberries. }\end{array}$ \\
\hline
\end{tabular}

lysozyme incorporated reduces the salmonella growth. In addition, pomegranate juices processed with PEF and stored in antimicrobial bottles can be conserved for long time. In Table 4 are described some studies related to electric field treatment for food preservation.

\subsection{Electromagnetic Field}

Magnetic fields application produce changes in the organisms to cell level due to the capacity to modulate the concentration of enzymes, the transport of ions, concentrations of hormones, and DNA transcription ${ }^{55-59}$. These effects are produced by the increase of the permeability of the plasma membrane due to that part of calcium bound to the phospholipids are removed by colloidal particles suspended in culture medium when the system is exposed to magnetic fields $\mathrm{s}^{60-62}$. Besides, some important factors that determine the effectiveness of this treatment are the range of frequency intensity and the operating conditions used to inactive the microorganism growth (i.e., dynamic or static test) ${ }^{63}$.

Researchers have reported the effect of magnetic fields on Escherichia coli and Salmonella enteritidis inoculated in liquid whole egg ${ }^{60}$. The results of this study indicated that a reduction of bacteria population was observed and that greater efficiencies are obtained with the highest time of treatment. In another study, it was determined that magnetic fields could increase the conductivity of the hemoglobin molecules in hatched chicks ${ }^{64}$. Similarly, magnetic fields did not affect the hatchability of eggs and chick weight at hatch ${ }^{65}$. Conversely, in another study, an increase in the egg hatchability is generated by the use of magnetic fields ${ }^{66}$.

Researchers also have demonstrated that electromagnetic fields enhance the microbial productivity as an example the polypeptides production ${ }^{\frac{67}{}}$, production of probiotic cultures for yogurt (i.e., Lactobacillus acidophilus, L.casei, and Bioyogurt $)^{68,69}$. Also, it has reported the design of a device for milk treatment used in the fabrication of white cheese. This device looks for the improvement the properties milk such as acidity, microbial growth, and cheese production ${ }^{70}$.

\subsection{High Hydrostatic Pressure (HHP)}

High Hydrostatic Pressure (HHP) causes effects on the composition of food such as volatile compounds, pigments, enzymes and bioactive compound ${ }^{71}$. In the food industry, this type of technology is used to the preservation of products. Hence, many researchers study the effects caused by the exposition of high hydrostatic pressure on the food.

Studies performed by Jing Shen and coworkers revealed that at values greater than or equal to $400 \mathrm{MPa}$ for 20 minutes caused inactivation of microorganism and allowed conserve the physicochemical properties in jujube pulp ${ }^{72}$. Similarly, other investigations have shown that the use of high hydrostatic pressures inactivates the growth of the microorganism in papaya drink without altering its properties ${ }^{71}$. Another study 
Table 4. Electric field treatment for food preservation

\begin{tabular}{|c|c|c|}
\hline Food Product & Operation Conditions & Principal Results \\
\hline $\begin{array}{l}\text { Carrot (Daucus carota var. } \\
\text { Nantes) }\end{array}$ & $\begin{array}{l}\text { PEF of } 162 \mathrm{~kJ} / \mathrm{kg}, 80 \mathrm{~Hz}, 3000 \text { pulses and } 0.6 \mathrm{kV} / \mathrm{cm} \text {; } \\
\text { Pre-conditioning temperature }\left(10,20,30 \text { and } 40^{\circ} \mathrm{C}\right) \text {. }\end{array}$ & $\begin{array}{l}\text { Inactivation of Ascorbic Acid Oxidase } \\
(\text { AAO) and Per-OxiDase (POD) at } \\
\text { least } 20 \% \text { to } 50 \% \text {. }\end{array}$ \\
\hline $\begin{array}{l}\text { Potatoes (Solanum } \\
\text { tuberosum, var. Rooster) }\end{array}$ & $\begin{array}{l}18.9 \mathrm{~kJ} / \mathrm{kg} \text { PEF treatmentsby applying } 9000 \text { pulses at } \\
0.75 \mathrm{kV} / \mathrm{cm} \text { electric field. }\end{array}$ & $\begin{array}{l}\text { Less absorption of oil when frying } \\
\text { potatoes. }\end{array}$ \\
\hline Pomegranate juice & $\begin{array}{l}\text { Laboratory scale (flow rate } 7.2 \mathrm{~L} / \mathrm{h} \text {, field strength of } \\
35 \mathrm{kV} / \mathrm{cm} \text {, time of } 72 \mu \mathrm{s} \text { ) and pilot scale (flow rate } 100 \\
\mathrm{~L} / \mathrm{h} \text {, field strength } 35 \mathrm{kV} / \mathrm{cm} \text {, time } 281 \mu \mathrm{s} \text { ). }\end{array}$ & $\begin{array}{l}\text { Juices treated with PEF had } 21 \text {-day } \\
\text { shelf life at laboratory scale, and more } \\
\text { than } 84 \text { days at pilot scale. }\end{array}$ \\
\hline Orange juice & $\begin{array}{l}\text { PEF with a field strength of } 90 \mathrm{kV} / \mathrm{cm}, 20 \text { pulses and } \\
55^{\circ} \mathrm{C} \text {. }\end{array}$ & $\begin{array}{l}\text { Reduction of Salmonella } \\
\text { typhimurium }\end{array}$ \\
\hline Avocado & $\begin{array}{l}\text { Field strength at } 10 \mathrm{kV} / \mathrm{cm} \text { at frequencies from } 0 \text { to } 950 \\
\text { Hz. Treatment times between } 0-6 \text { min. }\end{array}$ & $\begin{array}{l}\text { The minimal activity of } 12 \% \text { of the } \\
\text { enzyme Poly-Phenol Oxidases (PPO) } \\
\text { after } 6 \text { min at } 260 \mathrm{~Hz} \text {. }\end{array}$ \\
\hline
\end{tabular}

also indicated the inactivation of Listeria monocytogenes LGB and two braids of Zygosaccharomyces bailii in commercial shakes $\frac{73}{}$. In this study, also it was demonstrated the synergistic effect of temperature and HHP.

Studies realized in melon puree determined the inactivation of Salmonella enterica and Listeria monocytogenes by the application of HHP. Similarly, the growth of natural yeasts and molds and the total aerobic microorganisms in the puree also was reduced under this effect ${ }^{74}$. A similar result was evidenced in sweet cherries where the quality and safety microbiological characteristics were maintained ${ }^{75}$. The effects caused by HHP treatment and natural extracts in avocado puree induced an increase of free fatty acids, an inhibition of enzymatic activities, and protection of nutritional content $\frac{76}{}$. Similar results were observed in olive paste, where the application of HHP treatment induced a reduction in the presence of the microorganism, oxidative stability, and sensory acceptance ${ }^{77}$.

The application of HHP treatment in cereals reduced the enthalpy change of starch retrogradation and delayed water transformation freezable in non-releasable water during retrogradation ${ }^{78}$.

On the other hand, studies have found that the pressurization process used to attack a certain type of plague as example Anastrephaludens, which affects the physiology maturity of Magniferaindica. These microorganisms alter the consistency of the pulp and its physicochemical properties, which influence negatively in the acceptation of the product by the consume ${ }^{79}$.

In the meat industry, high hydrostatic pressures have been used as an alternative for the decrease of pathogenic microorganisms in processed products. Some studies related to the evaluation of the parameters of quality such as color, texture, exudate and microbiological stability in the beef under HHP has revealed that the different combinations of the treatments provide an acceptable color and microbiological stability during four and six weeks of storage during refrigeration. Other aspects such as the texture and the capacity of retention of water were significantly affected by the application of this effect ${ }^{80}$. Similarly, HHP combined with reuterin, Lacto-Peroxidase (LPS) and lacto-Ferrin (LF) in ham cooked in slices have an antimicrobial effect on pathogens (i.e., Enteritidis and $E$. coli O157: H7) $)^{81}$. A study performed by Jofre and coworkers in 2009 indicated that high pressures inactivate the growth of E. coli, yeast, and the foodborne pathogens $L$. monocytogenes, Salmonella, Y. enterocolitica and C. jejuni in baked sliced ham, dried slices cured and loin marinated res $^{82}$. Besides, it has reported the preservation of meat products of chicken by the synergistic effect between HHP and atmospheres of carbon dioxide ${ }^{\frac{83}{3}}$. In this study, both effects inactivated the growth of bacteria and pathogenic common. Hayes and coworkers also found the inactivation of $S$. aureus in meat by the combination of HHP and $\operatorname{nisin}^{84}$.

The antimicrobial effect of HHP in cheese also has been investigated. In a study ${ }^{85}$, it has reported the inac- 
tivation of Streptococcus thermophilus bacteriophages present in cheese exposed to pressures between 400-600 MPa for a time of 0-30 min.In another study, the effect of HHP on the reduction of fat in cheddar cheese, in order to improve its flavor and texture also has been evaluated. In this study ${ }^{86}$, the application of HHP resulted in a reduction of fat and a softer texture of the cheese. Lately, researchers have proposed the use of HHP with carbon dioxide atmospheres since affect the metabolism and growth of microorganism pathogens ${ }^{87}$.

On the other hand, studies indicate that consumers may find less acceptable the meat treated with HHP than untreated meat based on its sensory properties ${ }^{88,89}$ and also, substantial changes in the physicochemical, microbiological properties and organoleptic elements of meat stimulated with $\mathrm{HHP}^{90}$. Also, the effects antimicrobial caused by the pressurization in frozen carpaccio were not superior to the effects produced by thermal inactivation of the microorganism ${ }^{91}$. The authors of this study argue the lower water activity produced by HHP treatment during the centrifugation stage. In Table 5 are described recent studies related to HHP treatment in this field.

\section{Conclusion}

The application of non-thermal treatments used to preserve food products for example fruits, minimally processed fruits, juices, meat, milk product, vegeta- bles, etc., causes effects on their structure, achieving their sterilization and nutritional integrity. These nonthermal methods inactive the microbial load present in the food, conserve their functional properties and do not generate considerable changes in their mechanical properties.

The mechanism used by these techniques to attain the microbial inactivation is related to the capacity to generate damage to the cell level, which affect DNA transcription and replication process. Each treatment has advantages, which are based on the disinfection effect and the minimal alteration in the composition, structure, and physicochemical properties. Some of the advantages that offer this non-thermal treatment when are applied in food can highlight the followings:

- Good texture in food or desirable mechanical properties (i.e., hardness, elasticity, etc.),

- Minimal or no alteration of physicochemical properties (color, pH, acid, etc.),

- Desirables organoleptic characteristic,

- Production of edible microorganism,

- Localized heating without to use an intermediate fluid,

- Inhibition of the degree of browning. (i.e., fruits and vegetables),

- Conservation of the nutritional contents,

- Enzymes inactivation for avoid the food spoilage, and

- Antimicrobial effect on contaminant agents.

Table 5. High hydrostatic pressure treatment for food

\begin{tabular}{|c|c|c|}
\hline Food Product & Operation Condition & Microorganism \\
\hline Dry-cured Ham & $347-852 \mathrm{MPa}, 5 \mathrm{~min} / 15^{\circ} \mathrm{C}$ & Salmonella entérica. \\
\hline Sweet Cherries & $600 \mathrm{MPa}, 8 \mathrm{~min}$ and stored at $4{ }^{\circ} \mathrm{C}$ for 60 days & Gluconobacter and Enterobacteriaceae. \\
\hline Cantaloupe Puree & 300,400 and $500 \mathrm{MPa}$ at $8^{\circ} \mathrm{C}$ and $15^{\circ} \mathrm{C}$ for $5 \mathrm{~min}$ & $\begin{array}{l}\text { Salmonella enterica and } \\
\text { Listeria monocytogenes. }\end{array}$ \\
\hline Cheese & $400-600 \mathrm{MPa}$ and holding time (0-30 $\mathrm{min})$, & Streptococcusthermophilus. \\
\hline Meat Slurry & $350-550 \mathrm{MPa}, 3-12 \mathrm{~min}$ at room temperature & Staphylococcusaureus. \\
\hline Smoothies & $\begin{array}{l}100 \text { to } 300 \mathrm{MPa} \text { and } \\
\text { temperature }\left(5 \text { to } 45^{\circ} \mathrm{C}\right)\end{array}$ & $\begin{array}{l}\text { Listeria monocytogenes, } \\
\text { Zygosaccharomycesbailii. }\end{array}$ \\
\hline Poultry Sausages & $350 \mathrm{MPa} 10 \mathrm{~min}$ at room temperature & $\begin{array}{l}\text { Leuconostoccarnosum, } \\
\text { Brochothrixthermosphacta, Salmonella } \\
\text { enteritidis, Campylobacterjejuni and } \\
\text { Listeria innocua. }\end{array}$ \\
\hline Meat Products & $600 \mathrm{MPa}$ and storage at $4{ }^{\circ} \mathrm{C}$ & $\begin{array}{l}\text { Listeria monocytogenes, Salmonella } \\
\text { enterica, Staphylococcusaureus, Yersinia } \\
\text { enterocolitica and Campylobacterjejuni. }\end{array}$ \\
\hline
\end{tabular}


Non-thermal treatment is an option as a disinfection method for the food product; however, it is necessary for more studies in this area. These studies must be focused on determinate better operation conditions, exposition time, and the antimicrobial effect that can be used to carry out each type of treatment. Alike, the joint application of various technologies for the disinfection process can be useful. Some technologies that can be foregrounded in this area are the use of nanostructured material for food packaging, bioactive packaging, intelligent packaging, biodegradable packaging, enzymatic treatments, biocompounds, and biopreservation.

\section{Acknowledgment}

The authors are thankful to the University of Sucre for their support to the development of this study and for providing the tools necessary for successfully conclude this research.

\section{References}

1. Mathavi V, Sujatha G, Ramya S., Devi B. New trends in food processing, International Journal of Advances in Engineering and Technology. 2013; 5(2):176-87.

2. Barbosa-Canovas G, Fernandez-Molina J, Alzamora S, Tapia M, Lopez-Malo A, Chanes J. Handling and preservation of fruits and vegetables by combined methods for rural areas, Food and Agriculture Organization of the United Nations. 2003; 149:19-37.

3. McElhatton A, Marshall RJ. Food safety a practical and case study approach, Integrating Food Science and Engineering Knowledge in to the Food Chain. 2007.

4. Borata AB. Nuevas tecnologías de conservación de -alimentos. A. Madrid Vicente Ediciones; 2010. p. 1-7.

5. Balasubramaniam VM, Martínez-Monteagudo SI, Gupta R. Principles and application of high pressurebased technologies in the food industry, Annual Review of Food Science and Technology. 2015; 6(1):435-62. https://doi.org/10.1146/annurev-food-022814-015539 PMid: 25747234.

6. Fuentes L, Acevedo D, Gélvez VM. Efecto del ultrasonido y campos magnéticos en la carne de lomo atún (Thunnus albacares), Information Tecnology. 2016; 27(2):2130. https://doi.org/10.4067/S0718-07642016000200004.

7. Polo-CorralesL,Ramirez-VickJ,Feria-DiazJJ.Recentadvances in biophysical stimulation of MSC for bone regeneration,
Indian Journal of Science and Technology. 2018; 11(15):1-41. https://doi.org/10.17485/ijst/2018/v11i15/121405.

8. Birmpa A, Sfika V, Vantarakis A. Ultraviolet light and ultrasound as non-thermal treatments for the inactivation of microorganisms in fresh ready-to-eat foods, International Journal of Food Microbiology. 2013; 167(1):96-102. https://doi.org/10.1016/j.ijfoodmicro.2013.06.005. PMid: 23827815.

9. Hulsmans A, Joris $\mathrm{K}$, Lambert N, Rediers $\mathrm{H}$, Declerck P, Delaedt Y. Evaluation of process parameters of ultrasonic treatment of bacterial suspensions in pilot scale water disinfection system, Ultrasonics Sonochemistry. 2010; 17:1004-09. https://doi.org/10.1016/j.ultsonch.2009.10.013. PMid: 19962336.

10. Romero Barragán PE, Gélvez Ordó-ez VM. Bistua. Efectos de los campos magnéticos y el Ultrasonido sobre la Calidad microbiológica y las propiedades funcionales en una Emulsion de carne de bufalo (Bubalusbubalis), Bistua: Revista de la Facultad de Ciencias Básicas. 2013; 11(1):67-76.

11. Gelvez Ordo-ez VM, Campo-Vera Y, Villada-Castillo DC. Efecto del ultrasonido en las propiedades físicas de la leche entera, Bistua Rev la Fac Ciencias Básicas. 2015; 13(2):79-90.

12. Forghani F, Oh DH. Hurdle. Enhancement of slightly acidic electrolyzed water antimicrobial efficacy on Chinese cabbage, lettuce, sesame leaf and spinach using ultrasonication and water wash, Food Microbiology. 2013; 36(1):40-5. https://doi.org/10.1016/j.fm.2013.04.002. PMid: 23764218.

13. Sagong HG, Cheon HL, Kim SO, Lee SY, Park KH, Chung MS. Combined effects of ultrasound and surfactants to reduce Bacillus cereus spores on lettuce and carrots, International Journal of Food Microbiology. 2013; 160(3):367-72. https://doi.org/10.1016/j.ijfoodmicro.2012.10.014. PMid: 23290247.

14. Campo Y, Gélvez V. Efecto De La Termosonicación Sobre Las Propiedades Fisicoquímicas Del Hongo Comestible (Pleurotusostreatus) Fresco E Empacado Al Vacio, Revista La Fac Cienc Basicas. 2011; 9(2):55-63.

15. Vollmer M. Physics of the microwave oven, Physics Education. 2003; 39(1):74-81. https://doi.org/10.1088/0031-9120/39/1/006.

16. Tang J, Chow Ting Chan TV. Microwave and radio frequency in sterilization and pasteurization applications. In: Heat Transfer in Food Processing; 2007. p. 101-57.

17. Barbosa-Cánovas GV, Medina-Meza I, Candogan K, Bermúdez-Aguirre D. Advanced retorting, Microwave Assisted Thermal Sterilization (MATS), and Pressure Assisted Thermal Sterilization (PATS) to process 
meat products, Meat Science. 2014: 98(3):420-34. https://doi.org/10.1016/j.meatsci.2014.06.027. PMid: 25060584

18. Datta A, Anantheswaran R. Handbook of microwave technology for food applications. First edit. New York: Marcel Dekker Press; 2001. p. 536. https://doi.org/10.1201/9781482270778.

19. Zhu X, Yang Y, Duan Z. Research progress on the effect of microwave sterilization on agricultural products quality, IOP Conference Series: Earth and Environmental Science. 2018; 113:1-5. https://doi.org/10.1088/1755-1315/113/1/012096.

20. Kalla AM, Devaraju R. Microwave energy and its application in food industry: A review, Asian Journal of Dairy and Food Research. 2017; 36:37-44. https://doi.org/10.18805/ajdfr.v0iOF.7303.

21. Xu XL, Shi RC. Effect of Microwave Treatment on the Sterilization Effect and Quality of Mango Puree, Chinese Journal of Tropical Crops. 2017; 38(3):572-9.

22. Yu XL, Shi RC, Wang L. Effect of microwave treatment on the quality of Carica Papaya L. puree, Food Science and Technology. 2016; (5):64-70.

23. Xiao N, He JM, Li T. Micro-wave Sterilization of Sanhuali Fruit Cake, Modern Food Scienceand Technology. 2013; 29(5):1093-5.

24. Wu Z, Zhang K, Zhao GH. Microwave Sterilization of Wet Noodles with Pumpkin Extending Shelf-life effectively, Food Ferment Technology. 2010; 46(6):22-5.

25. Zhang $H$, Bhunia K, Kuang P. Effects of oxygen and water vapor transmission rates of polymeric pouches on oxidative changes of microwave-sterilized mashed potato, Food Bioprocess Technology. 2016; 9(2):1-11. https://doi.org/10.1007/s11947-015-1628-3.

26. Biao Q, Chao Q, Xiao-yu C, Wen-hua C, Shun-liang Z, Shu-yang XIE. Effect of microwave sterilization on quality properties of Stewed Pork Liver, Food and Science. 2013; 34(1):69-72.

27. Xu YY, Li KJ, Qiu Y. Process optimization of microwave sterilization for Aspergillus niger from rice, Science and Technology of Food Industry. 2014; 35(22):245-8.

28. Cinquanta L,AlbaneseD, CuccurulloG,DiMatteo M.Effecton orange juice of batch pasteurization in an improved pilot-scale microwave oven, Journal of Food and Science. 2010; 75(1):4650. https://doi.org/10.1111/j.1750-3841.2009.01412.x. PMid: 20492165.

29. Velásquez ÁM, Sánchez A, León R. Utilización de microondas en el tratamiento de jugo de mango, Revista Lasallista de Investigación. 2008; 5(2):13-9.

30. De La Vega-Miranda B, Santiesteban-López NA, LópezMalo A, Sosa-Morales ME. Inactivation of Salmonella typhimurium in fresh vegetables using water-assisted microwave heating, Food Control. 2012; 26(1):19-22. https://doi.org/10.1016/j.foodcont.2012.01.002.

31. Jamshidi A, Seifi HA, Kooshan M. The effect of short-time microwave exposures on Escherichia coli O157: H7 inoculated onto beef slices, African Journal of Microbiology Research. 2010; 4(22):2371-74.

32. Redondo D, Venturini ME, Oria R, Arias E. Inhibitory effect of microwaved thinned nectarine extracts on polyphenol oxidase activity, Food Chemistry. 2016; 197:603-10. https://doi.org/10.1016/j.foodchem.2015.11.009. PMid:26616994.

33. Choudhary R, Bandla S. Ultraviolet pasteurization for food industry, International Journal of Food Science and Nutrition Engineering. 2012; 2(1):12-5. https://doi.org/10.5923/j.food.20120201.03.

34. Ultraviolet radiation for the processing and treatment of food. Date accessed: 2000. https://www.law.cornell.edu/cfr/text/21/179.39.

35. Nimitkeatkai $H$, Kulthip J. Effect of sequential UV-C irradiation on microbial reduction and quality of freshcut dragon fruit, International Food Research Journal. 2016; 23(4):1818-22.

36. Bank HL, Schmehl JL, Dratch RJ. Bacteriocidal effectiveness of modulated UV light, Applied and Environmental Microbiology. 1990; 56:3888-89. PMid: 2128016, PMCid: PMC185087.

37. Kalyani B, Manjula K. Review article food irradiation - Technology and application, International Journal of Current Microbiology and Applied Sciences. 2014; 3(4):549-55.

38. Koutchma T. UV light for processing foods, Ozone: Science and Engineering. 2008; 30(1):93-8. https://doi.org/10.1080/01919510701816346.

39. Manzocco L, Da Pieve S, Maifreni M. Impact of UV-C light on safety and quality of fresh-cut melon, Innovative Food Science and Emerging Technologies. 2011; 12(1):13-7. https://doi.org/10.1016/j.ifset.2010.11.006.

40. Holck A, Liland K, Drømtorp S, Carlehög M, McLEOD A. ComparisonofUV-CandpulsedUVlighttreatmentsforreduction of salmonella, Listeria Monocytogenes, and Enterohemorrhagic Escherichia coli on eggs, Journal of Food Protection. 2018; 81(1):1-31. https://doi.org/10.4315/0362-028X.JFP-17-128. PMid: 29220202.

41. Ignat A, Manzocco L, Maifreni M, Bartolomeoli I, Nicoli MC. Surface decontamination of fresh-cut apple by pulsed light: Effects on structure, colour and sensory properties, Postharvest Biology and Technology. 2014; 91(2-3):122-7. https://doi.org/10.1016/j.postharvbio.2014.01.005.

42. Márquez Villacorta L, Pretell Vásquez C. Irradiación UV-C en frutas tropicales mínimamente procesadas, 
Scientia Agropecuaria. 2013; 4(2):147-61. https://doi.org/10.17268/sci.agropecu.2013.03.01.

43. Adhikari A, Syamaladevi RM, Killinger K, Sablani SS. Ultraviolet-C light inactivation of Escherichia coli O157: H7 and Listeria monocytogenes on organic fruit surfaces, International Journal of Food Microbiology. 2015; 210:136-142. https://doi.org/10.1016/j.ijfoodmicro.2015.06.018. PMid: 26122954.

44. Raybaudi-Massilia R, Calderón-Gabaldón MI, MosquedaMelgar J, Tapia MS. Inactivation of Salmonella enterica ser. Poona and Listeria monocytogenes on fresh-cut "Maradol" red papaya (Carica papaya L) treated with UV-C light and malic acid, Journal für Verbraucherschutz und Lebensmittelsicherheit. 2013; 8(1-2):37-44.

45. Zhao W, Yang RJ, Zhang HQ. Recent advances in the action of pulsed electric fields on enzymes and food component proteins, Trends in Food Science and Technology. 2012; 27(2):83-96. https://doi. org/10.1016/j.tifs.2012.05.007.

46. Zimmermann U. Electrical breakdown, electropermeabilization and electrofusion, Reviews of Physiology, Biochemistry and Pharmacology. 1986; 105:176-256. https://doi.org/10.1007/BFb0034499. PMid: 3541139.

47. Ignat A, Manzocco L, Brunton NP, Nicoli MC, Lyng JG. The effect of pulsed electric field pre-treatments prior to deep-fat frying on quality aspects of potato fries, Innovative Food Science and Emerging Technologies. 2015; 29:65-9. https://doi.org/10.1016/j.ifset.2014.07.003.

48. Leong SY, Richter LK, Knorr D, Oey I. Feasibility of using pulsed electric field processing to inactivate enzymes and reduce the cutting force of carrot (Daucus carota var. Nantes), Innovative Food Science and Emerging Technologies. 2014; 26:159-67. https://doi.org/10.1016/j.ifset.2014.04.004.

49. Castorena-Garciı JH, Martınez-Montes FJ, Robles-Lopez MR, Welti-Chanes JS, Hernandez-Sanchez H, Roblesde-la-Torre RR. Effect of Electric Fields on the Activity of Polyphenol Oxidases, Revista Mexicana de Ingeniería Química. 2013; 12(3):391-400.

50. Ruan R, Deng S, Cheng Y. Concentrated High Intensity Electric Field (CHIEF) pasteurization of milk, Midwest Dairy Foods Res Cent. 2010; 183-8.

51. Faridnia F, Burritt JD, Bremer P, Oey I. Innovative approach to determine the effect of pulsed electric fields on the microstructure of whole potato tubers: Use of cell viability, microscopic images and ionic leakage measurements, Food Research International. 2015; 77(3):556-64. https://doi.org/10.1016/j.foodres.2015.08.028.

52. Fauster T, Schlossnikl D, Rath F, Ostermeier R, Teufel F, Toepfl F. Impact of Pulsed Electric Field (PEF) pretreatment on process performance of industrial French fries production, Journal of Food Engineering. 2018; 235:16-22. https://doi.org/10.1016/j.jfoodeng.2018.04.023.

53. Liang Z, Mittal GS, Griffiths MW. Inactivation of Salmonella typhimurium in orange juice containing antimicrobial agents by pulsed electric field, Journal of Food Protection. 2002; 65(65):1081-87. https://doi.org/10.4315/0362-028X-65.7.1081. PMid: 12117238.

54. Jin TZ, Guo M, Yang R. Combination of pulsed electric field processing and antimicrobial bottle for extending microbiological shelf-life of pomegranate juice, Innovative Food Science and Emerging Technologies. 2014; 26:153-8.

55. Nafziger J, Desjobert H, Benamar B, Guillosson J., Adolphe M. DNA mutations and $50 \mathrm{~Hz}$ electromagnetic fields, Bioelectrochemistry Bioenergy. 1993; 30:133-41. https://doi.org/10.1016/0302-4598(93)80071-2.

56. Goodman R, Shirley-Henderson A. Transcription and translation in cells exposed to extremely low frequency electromagnetic fields, Journal of Electroanalytical Chemistry and Interfacial Electrochemistry. 1991; 320(3):335-55. https://doi.org/10.1016/00220728(91)85651-5.

57. D’Inzeo G, Pisa S, Tarricone L. Ionic channel gating under electromagnetic exposure: A stochastic model, Bioelectrochemistry Bioenergy. 1993; 29(3):289-304. https://doi.org/10.1016/0302-4598(93)85004-D.

58. Yadollahpour A, Jalilifa M, Rashidi S. Antimicrobial effects of electromagnetic fields: A review of current techniques and mechanisms of action, Journal of Pure and Applied Microbiology. 2014; 8(5):4031-43.

59. Novickij V, Grainys A, Lastauskienè E, Kananavičiūtė R, Pamedytytè D, Kalèdienè L. Pulsed electromagnetic field assisted in vitro electroporation: A pilot study, Scientific Reports. 2016; 6(1):33537. https://doi.org/10.1038/srep33537. PMid: 27634482, PMCid: PMC5025861.

60. Gélvez VM, Hernández S, Campo-Vera Y. Inactivación de bacterias patógenas por efecto de campos magnéticos, Agron Colomb. 2016; 34:1462-4.

61. Liboff A, Williams T, Strong DM, Wistar R. Time varying magnetic fields: Effect on DNA synthesise, Science (80- ). 1984; 223(4638):818-20.

62. Pothakamury U, Barbosa-Canovas G, Swanson BG. Magnetic-field inactivation of microorganisms and generation of biological changes, Food Technology. 1993; 47(12):85-93.

63. Haile $\mathrm{M}$, Zhongli $\mathrm{P}$, Mengxiang $\mathrm{G}$, Luo L. International Journal of Food Efficacy in Microbial Sterilization of Pulsed Magnetic Field Treatment Efficacy in Microbial Sterilization of Pulsed Magnetic Field Treatment, 
International Journal of Food Engineering. 2008; 4(4):114. https://doi.org/10.2202/1556-3758.1177.

64. Mohamed GM, Mohamed ST, Abd-Alaah AA, Kassem AMA, Suliman AAM. Effect of incubating egg exposure to magnetic field on the biophysical blood properties of newly-hatched chicks, Pakistan Journal of Pharmaceutical Sciences. 2015; 28(5):1865-70. PMid: 26525029.

65. Shafey TM, Aljumaah RS, Swillam SA, Al-mufarrej SI, Al-abdullatif AA, Ghannam MM. Effects of short term exposure of eggs to magnetic field before incubation on hatchability and post-hatch performance of meat chickens, Saudi Journal of Biological Sciences. 2011; 18(4):3816. https://doi.org/10.1016/j.sjbs.2011.06.004. PMid: 23961150 , PMCid: PMC3730795.

66. Tarasewicz Z, Szczerbinska D, Majewska D, Danczak A, Ligocki M, Wolska A. The effect of magnetic field on hatchability of Japanese quail eggs, Czech Journal of Animal Science. 2006; 51(8):35560. https://doi.org/10.17221/3951-CJAS.

67. Mohtasham P, Keshavarz-moore E, Kale I, Keshavarz T. Application of magnetic field for improvement of microbial productivity, Chemical Engineering Transactions. 2016; 49:43-8.

68. Guzmán TM, Anaya-Villalpanda M, Mesa-Mari-o Y. Activación de cultivos probióticos tratados con campo magnético de frecuencia extremadamente baja, Tecnol Quim. 2016; 36(1):106-16.

69. Jean-felix K, Ivanovich KG. Intensification of production yogurt technology with activation of the leaven with the electromagnetic field of low frequency, Technology Science. 2015; 108(4):1-11.

70. Ali HI, Al-Hilphy ARS, Al-Darwash AK. The effect of magnetic field treatment on the characteristics and yield of Iraqi local white cheese, Journal of Agriculture and Veterinary Science. 2015; 8(9):2319-72.

71. Chen D, Pang X, Zhao J, Gao L, Liao X, Wu J. Comparing the effects of high hydrostatic pressure and high temperature short time on papaya beverage, Innovative Food Science and Emerging Technologies. 2015; 32:16-28. https://doi.org/10.1016/j.ifset.2015.09.018.

72. Shen J, Gou Q, Zhang Z, Wang M. Effects of high hydrostatic pressure on the quality and shelf-life of jujube (Ziziphusjujuba Mill.) pulp, Innovative Food Science and Emerging Technologies. 2016; 36:166-72. https://doi.org/10.1016/j.ifset.2016.06.019.

73. Scolari G, Zacconi C, Busconi M, Lambri M. Effect of the combined treatments of high hydrostatic pressure and temperature on Zygosaccharomyces bailii and Listeria monocytogenes in smoothies, Food Control. 2015; 47:16674. https://doi.org/10.1016/j.foodcont.2014.07.006.

74. Mukhopadhyay S, Sokorai K, Ukuku D, Fan X, Juneja V, Sites J, et al. Inactivation of Salmonella enterica and Listeria monocytogenes in cantaloupe puree by high hydrostatic pressure with/without added ascorbic acid, International Journal of Food Microbiology. 2016; 235:77-84. https://doi.org/10.1016/j.ijfoodmicro.2016.07.007. PMid: 27441819.

75. Toledo del Arbol J, Perez Pulido R, La Storia A, Grande Burgos MJ, Lucas R, Ercolini D, et al. Microbial diversity in pitted sweet cherries (Prunus avium L.) as affected by High-Hydrostatic Pressure treatment, Food Research International. 2016; 89:790-6. https://doi.org/10.1016/j.foodres.2016.10.014. PMid: 28460980.

76. Jacobo-Velázquez DA, Castellanos-Dohnal G, CaballeroMata P, Hernández-Brenes C. Cambios bioquímicos durante el almacenamiento de puré de aguacate adicionado con antioxidantes naturales y procesado con alta presión hidrostática, CYTA - Journal of Food. 2013; 11(4):379-91.

77. Sánchez J, De Miguel C, Ramírez MR, Delgado J, Franco MN, Martín D. Efecto de las altas presiones hidrostáticas respecto a la pasteurización térmica en los aspectos microbiológicos, sensoriales y estabilidad oxidativa de un paté de aceituna, Grasas y Aceites. 2012; 63(1):100-8. https://doi.org/10.3989/gya.071211.

78. Tian Y, Li D, Zhao J, Xu X, Jin Z. Effect of High Hydrostatic Pressure (HHP) on slowly digestible properties of rice starches, Food Chemistry. 2014; 152:225-9. https://doi.org/10.1016/j.foodchem.2013.11.162. PMid: 24444930.

79. Álvarez-Virrueta DR, García-López EG, Montalvo-González E, Ramírez JA, Mata-Montes-De-Oca M, Tovar-Gómez B. Effect of high hydrostatic pressure on postharvest physiology of the "ataulfo" mango, CYTA - Journal of Food. 2012; 10(3):17381. https://doi.org/10.1080/19476337.2011.603843.

80. Giménez B, Graiver N, Califano A, Zaritzky N. Physicochemical characteristics and quality parameters of a beef product subjected to chemical preservatives and high hydrostatic pressure, Meat Science. 2015; 100:17988. https://doi.org/10.1016/j.meatsci.2014.10.017. PMid: 25460123.

81. Montiel R, Martín-Cabrejas I, Peirotén Á, Medina M. Reuterin, lactoperoxidase, lactoferrin and high hydrostatic pressure treatments on the characteristics of cooked ham, 
Innovative Food Science and Emerging Technologies. 2016; 35:111-8. https://doi.org/10.1016/j.ifset.2016.04.013.

82. Jofré A, Aymerich $\mathrm{T}$, Grèbol $\mathrm{N}$, Garriga $\mathrm{M}$. Efficiency of high hydrostatic pressure at $600 \mathrm{MPa}$ against food-borne microorganisms by challenge tests on convenience meat products, LWT - Food Science Technology. 2009; 42(5):924-8. https://doi. org/10.1016/j.lwt.2008.12.001.

83. Al-Nehlawi A, Guri S, Guamis B, Saldo J. Synergistic effect of carbon dioxide atmospheres and high hydrostatic pressure to reduce spoilage bacteria on poultry sausages, LWT - Food Science Technology. 2014; 58(2):404-11. https://doi.org/10.1016/j.lwt.2014.03.041.

84. Yao J, Zhou B, Wang R, Wang T, Hu X, Liao X. Inactivation of staphylococcus aureus by high hydrostatic pressure in saline solution and meat slurry with different initial inoculum levels, Food Bioprod Process. 2015; 94(17):592-600. https://doi.org/10.1016/j.fbp.2014.06.005.

85. Zhang L, Qu M, Yao J, Wang P, Liao X, Hu X, et al. Effect of high hydrostatic pressure on the viability of Streptococcus thermophilus bacteriophages isolated from cheese, Innovative Food Science and Emerging Technologies. 2015; 29:113-8. https://doi.org/10.1016/j.ifset.2015.02.001.

86. Ozturk M, Govindasamy-Lucey S, Jaeggi JJ, Houck K, Johnson ME, Lucey JA. Effect of various highpressure treatments on the properties of reduced-fat Cheddar cheese, Journal of Dairy Science. 2013; 96(11):6792-806. https://doi.org/10.3168/jds.20126483. PMid: 24054280.
87. Bover-Cid S, Belletti N, Aymerich T, Garriga M. Modelling the impact of water activity and fat content of dry-cured ham on the reduction of Salmonella enterica by high pressure processing, Meat Science. 2017; 123:120-5. https://doi. org/10.1016/j.meatsci.2016.09.014. PMid: 27710771.

88. Hayes JE, Raines CR, DePasquale DA, Cutter CN. Consumer acceptability of High Hydrostatic Pressure (HHP) - treated ground beef patties, LWT - Food Science Technology. 2014; 56(1):207-10. https://doi.org/10.1016/j. lwt.2013.11.014.

89. Lorido L, Estévez M, Ventanas J, Ventanas S. Comparative study between Serrano and Iberian dry-cured hams in relation to the application of high hydrostatic pressure and temporal sensory perceptions, LWT - Food Science Technology. 2015; 64(2):1234-42. https://doi.org/10.1016/j.lwt.2015.07.029.

90. Omer MK, Prieto B, Rendueles E, AlvarezOrdo-ez A, Lunde K, Alvseike O. Microbiological, physicochemical and sensory parameters of dry fermented sausages manufactured with high hydrostatic pressure processed raw meat, Meat Science. 2015; 108:115-9. https://doi.org/10.1016/j.meatsci.2015.05.002. PMid: 26093224.

91. Szerman N, Barrio Y, Schroeder B, Martinez P, Sancho AM, Sanow C. Effect of high hydrostatic pressure treatments on physicochemical properties, microbial quality and sensory attributes of beef carpaccio, Procedia Food Science. 2011; 1:854-61. https://doi.org/10.1016/j.profoo.2011.09.129. 